Studi Pembuatan Fruit Leather Pisang Kepok Merah - Faradina, dkk Jurnal Pangan dan Agroindustri Vol.6 No.4: 49-58, Oktober 2018

\title{
STUDI PEMBUATAN FRUIT LEATHER PISANG KEPOK MERAH (KAJIAN KONSENTRASI KARAGENAN DAN SUKROSA)
}

\section{The Study of Making Fruit Leather Red Kepok Banana (Studies Concentration of Carrageenan and Sucrose)}

\author{
Devia Fajar Haqsari Faradina*, Yunianta \\ Jurusan Teknologi Hasil Pertanian, FTP Universitas Brawijaya Malang \\ Jl. Veteran, Malang 65145 \\ *Penulis Korespondensi, email: haqsadevia@gmail.com
}

\begin{abstract}
ABSTRAK
Fruit Leather adalah jenis olahan makanan berbasis convectionary terbuat dari buah buahan, berbentuk lembaran tipis dan rasanya khas tergantung dari jenis buah yang digunakan. Pisang merupakan komoditas unggulan di Indonesia namun buah pisang mudah mengalami kerusakan fisik, kimia dan mkrobiologi karenanya pisang memiliki masa simpan yang pendek.sebab itu perlu diversifikasi produk menjadi fruit leather. Penelitian ini menggunakan Rancangan Acak Lengkap dengan dua factor. Faktor pertama yaitu konsentrasi sukrosa $20 \% ; 30 \% ; 40 \%$ dan faktor kedua yaitu konsentrasi karagenan $0.5 \%, 1 \%$, 1.5\%. Hasil penelitian dianalisis dengan ANOVA dilanjutkan uji BNT/DMRT 5\%. Perlakuan terbaik dihasilkan dari kombinasi perlakuan karagenan $1.5 \%$ dan sukrosa $20 \%$ dengan kadar air sebesar $11.08 \%$, total asam $0.85 \%$, total gula $28.74 \%$, serat kasar $1.80 \%$, pH $4.50 \%$, nilai kecerahan 63.40, nilai kemerahan 3.73, nilai kekuningan 22.90, nilai kesukaan parameter warna 2.68, nilai kesukaan parameter rasa 2.88, nilai kesukaan parameter aroma 3.03, nilai kesukaan parameter tekstur 2.95 dan nilai kesukaan keseluruhan karakteristik 2.93.
\end{abstract}

Kata kunci: Fruit Leather, Karagenan, Pisang Kepok Merah, Sukrosa

\section{ABSTRACT}

Fruit Leather is a type of convectionary food based product. Banana is one of Indonesian leading fruit commodities. Therefore it is necessary to diversify banana product such as fruit leather. This research used Completely Randomized Design with two factors. The first factor was sucrose concentration (20\%; 30\%; 40\%) and the second factor was carrageenan concentration $(0.5 \%, 1 \%, 1.5 \%)$. The data obtained from the research was analyzed by ANOVA followed by BNT/DMRT test with $5 \%$. The best treatment based on physical and chemical characteristic is the treatment with carrageenan $1.5 \%$ and sucrose $20 \%$. The product has characteristic as follows water content $11.08 \%$, total acid $0.85 \%$, total sugar $28.74 \%$, crude fiber $1.80 \%$, pH 4.50\%, color $\left(L^{*}\right) 63.4$, color $\left(a^{*}\right) 3.73$, color $\left(b^{*}\right) 22.90$. The best treatment based on organoleptic is the treatment with carrageenan $1 \%$ and sucrose $30 \%$ which has characteristic as follows aroma 3.03, color 2.68, taste 3.50, texture 2.95 and overall characteristics 2.93.

Keywords: Banana, Carrageenan, Fruit Leather, Sucrose

\section{PENDAHULUAN}

Fruit leather merupakan salah satu bentuk olahan buah-buahan yang mempunyai nilai ekonomis di pasar internasional. Produk ini memiliki daya simpan lebih dari 12 bulan apabila disimpan dalam keadaan baik (Epetani.pertanian, 2010). Buah pisang merupakan salah satu sumber pangan lokal yang melimpah dan menjadi salah satu komoditas buah unggulan di Indonesia. Produksi pisang di Indonesia mencapai 7.007 .117 ton yaitu sekitar $5.97 \%$ dari total 
produksi pisang dunia (Pusat Data dan Informasi Pertanian, 2014). Pemanfaatan buah pisang selama ini belum optimal masih terbatas sebagai buah konsumsi segar dan produk olahan tradisional baik dari buah pisang mentah maupun dari buah pisang masak. Menurut Surendranathan (2003), pisang merupakan buah yang mudah busuk karena kadar airnya yang cukup tinggi. Selain itu ketika pisang masak teksturnya akan lembut dan umur simpanya hanya sekitar 7-8 hari. Salah satu upaya yang dapat dilakukan untuk menghindari pisang yang terbuang ialah dengan pembuatan leather berbahan baku buah pisang. Selain lebih tahan lama, buah pisang yang bentuknya kurang baik, ukurannya kecil, dan kulit buahnya cacat sehingga tidak mungkin disajikan sebagai buah segar, dapat diolah menjadi leather buah pisang.

\section{BAHAN DAN METODE}

\section{Bahan}

Bahan baku utama digunakan dalam proses pembuatan fruit leather adalah buah pisang kepok yang sudah matang atau umumnya sudah dapat dikonsumsi buahnya dari pasar Merjosari Malang. Sedangkan bahan tambahan lain yang digunakan dalam pembuataan fruit leather adalah Gula (Sukrosa) merk Gulaku, Karagenan jenis kappa karagenan dan asam sitrat yang diperoleh dari toko bahan kimia makmur Malang. Sedangkan bahan yang digunakan untuk analisis kimia meliputi aquades, Anthrone, natrium hidroksida $(\mathrm{NaOH})$, asam sulfat $\left(\mathrm{H}_{2} \mathrm{SO}_{4}\right)$ pekat, $\mathrm{HCL}$, kertas lakmus merah dan biru, indicator $\mathrm{PP}, \mathrm{CaCO} 3$ yang diperoleh dari Laboratorium Pengolahan, Laboratorium Biokimia, Laboratorium Bioteknologi Pangan dan Laboratorium Nutrisi jurusan Teknologi hasil Pertanian dan Toko bahan kimia di Kota Malang.

\section{Alat}

Alat yang digunakan dalam pembuatan Leather Buah Pisang Kepok meliputi baskom, sendok, pisau stainles steel, kompor, blander merk National timbangan digital, Spatula, Loyang aluminium ukuran $20 \times 10 \times 5 \mathrm{~cm}$, tissue, timbangan analitik merk Denver Instrument M310 , gelas ukur $100 \mathrm{ml}$, dan panci. Sedangkan alat yang digunakan untuk analisis kimia meliputi gelas ukur $100 \mathrm{ml}$, Tabung reaksi, Erlenmeyer $250 \mathrm{ml}$ dan $500 \mathrm{ml}$, beaker glass 250 $\mathrm{ml}$ dan $500 \mathrm{ml}$, labu ukur $100 \mathrm{ml}$, pipet volume $1 \mathrm{ml}$, bola hisap, cawan petri, cawan aluminium, cawan porselen, kerrtas saring halus, kertas saring whatman 40 , spatula kaca, corong plastik, tissue, pipet tetes, pemanas listrik $300 \mathrm{~W}$ merk Maspion, oven listrik merk Memmert Jerman, bola hisap merk Sicherheits, Color reader merk Konica Minolta, labu ukur $10 \mathrm{ml}$, pemegang buret, Pnetrometer electric BI-235, Vortex, Desikator, dan Spektrofotometer.

\section{Desain Penelitian}

Penelitian ini menggunakan metode analisis Analysis of Variance (ANOVA). Apabila terdapat perbedaan dan interaksi maka dilanjutkan dengan uji Duncan's Multiple Range Test (DMRT) dengan taraf nyata $(\alpha=5 \%)$. Namun apabila dari hasil uji terdapat perbedaan dan tidak ada interaksi maka dilanjutkan dengan uji Beda Nyata Terkecil (BNT) dengan taraf nyata $(\alpha=5 \%)$. Selanjutnya dilakukan pemilihan terbaik ditentukan dengan metode Multiple Objective Decision Making (MODM) (Zeleny, 1982).

\section{Tahapan Penelitian \\ Penelitian Pendahuluan}

Penelitian pendahuluan yang telah dilakukan diantaranya mencari formulasi pencampuran bahan tambahan dalam pembuatan "Leather" Buah Pisang Kepok Merah yaitu konsentrasi karagenan dan mencari konsentrasi Sukrosa. Berdasarkan penelitian pendahuluan diperoleh 9 kombinasi perlakuan yang selanjutnya dilakukan analisis.

\section{Pelaksanaan Penelitian}

Pisang kepok dikupas setelah itu dikukus selama 2 menit pada suhu $80^{\circ} \mathrm{C}$ kemudian di blender hingga halus dengan penambahan air yaitu dengan perbandingan 1 bagian puree berbanding 2 bagian air dan didapatkanlah puree buah yang kemudian akan ditambahkan 
sukrosa, karagenan dan asam sitrat kemudian dicampur dengan dipanaskan selama 2 menit dengan suhu $100^{\circ} \mathrm{C}$ kemudian dituang kedalam Loyang dan dikeringkan dalam cabinet dryer yang bersuhu $60^{\circ} \mathrm{C}$ selama 5 jam. Selanjutnya dilakukan analisis.

\section{Prosedur Analisis}

Analisis penelitian ini meliputi analisis yang dilakukan meliputi kadar air (AOAC, 1970), serat kasar (AOAC, 1970), total gula metode anthrone (Apriyantono dkk, 1989), total asam (AOAC, 1970), pH (Apriyantono dkk, 1989), tekstur dengan pnetrometer (Yuwono dan Susanto, 1998), Warna L*, a+, b+ Colour reader, (Yuwono dan Susanto, 1998), Organoleptik Uji Hedonik dan uji perlakuan terbaik (Zeleny,1982).

\section{HASIL DAN PEMBAHASAN}

\section{Karakteristik Bahan Baku}

Data karakteristik bahan baku fruit leather pisang kepok merah dapat dilihat pada Tabel 1.

Tabel 1. Karakteristik Bahan Baku (Puree Buah Pisang Kepok Merah)

\begin{tabular}{lc}
\hline \multicolumn{1}{c}{ Parameter } & Puree Buah Pisang Kepok Merah \\
\hline Kadar Air (\% wb) & 78.35 \\
Kadar Total Asam (\%) & 0.16 \\
Kadar Total Gula (\%) & 1.62 \\
Kadar Serat Kasar (\%) & 0.53 \\
pH & 6.00 \\
Warna & \\
- Kecerahan (L) & 54.60 \\
- Kemerahan (a*) & 4.00 \\
- Kekuningan $\left(\mathrm{b}^{*}\right)$ & 20.40 \\
\hline
\end{tabular}

Berdasarkan Tabel 1 dapat dilihat bahwa kadar air dalam puree buah pisang kepok sangat tinggi hal itu disebabkan oleh penambahan air dalam pembuatan puree buah dengan proporsi 2 : 1 yaitu 2 bagian air dan 1 bagian buah pisang kepok merah. Kadar air dalam bahan mempengaruhi sifat fisik dan kimia bahan tersebut (Musfiroh, 2009). Kadar total asam puree buah pisang kepok merah sangat rendah sekitar $0.16 \%$. Menurut Winarno (2002) total asam pada buah semakin menurun disebabkan terjadinya reaksi oksidasi saat pengirisan menggunakan pisau dan penghancuran daging buah dengan blender. Sementara untuk kadar total gula puree buah pisang kepok merah mencapai $1.62 \%$ dan kadar serat kasar hanya mencapai $0.53 \%$. Rendahnya kadar total asam, kadar total gula dan kadar serat kasar berkaitan dengan tingginya kadar air dalam bahan baku. Tingginya kadar air pada puree buah berpengaruh pada kadar total padatan terlarut meliputi kadar total asam, kadar total gula dan kadar serat kasar. Semakin tinggi kadar air yang mendominasi bahan maka akan semakin rendah total padatan yang terlarut didalamnya (Ferdinaz, 1986).

Nilai $\mathrm{pH}$ dari pure buah pisang kepok merah mencapai 6 yang berarti sedikit asam. Hal tersebut berkaitan dengan kadar total asam dimana jumlah total asam dalam bahan menentukan nilai $\mathrm{pH}$ bahan tersebut (Ishma, 2017). Hal tersebut didasarkan pada prinsip pengukuran $\mathrm{pH}$ dengan menggunakan $\mathrm{pH}$ meter yaitu dengan mengukur potensial elektrokimia dari ion hidrogen $\left(\mathrm{H}^{+}\right)$atau $\left(\mathrm{OH}^{-}\right)$, keberadaan ion $\left(\mathrm{H}^{+}\right)$yang lebih banyak mengakibatkan sifat larutan menjadi asam sementara dominasi ion $\left(\mathrm{OH}^{-}\right)$daam larutan mengakibatkan larutan tersebut bersifat basa (Rifky, 2014). Dengan semakin tinggi total asam $\left(\mathrm{H}^{+}\right)$dalam bahan maka nilai pH akan semakin kecil (semakin asam). Hal tersebut didukung pernyataan Sunarlim dan Misgiarta (2008) bahwa nilai pH berkebalikan dengan nilai total asam, dimana semakin tinggi nilai $\mathrm{pH}$ suatu bahan maka akan semakin rendah total asam pada bahan tersebut. 


\section{Karakteristik Kimia Fruit Leather Pisang Kepok Merah a. Kadar air}

Hasil Analisis sidik ragam menunjukkan penambahan konsentrasi karagenan dan penambahn konsentrasi sukrosa memiliki pengaruh nyata $(\alpha=0.05)$ terhadap kadar air fruit leather pisang kepok merah. Interaksi antar kedua faktor menujukkan adanya pengaruh nyata $(\alpha=0.05)$ terhadap kadar air fruit leather pisang kepok merah. Pengaruh Konsentrasi Karagenan dan Sukrosa terhadap Kadar Air Fruit Leather Pisang Kepok Merah dapat dilihat pada Gambar 1.

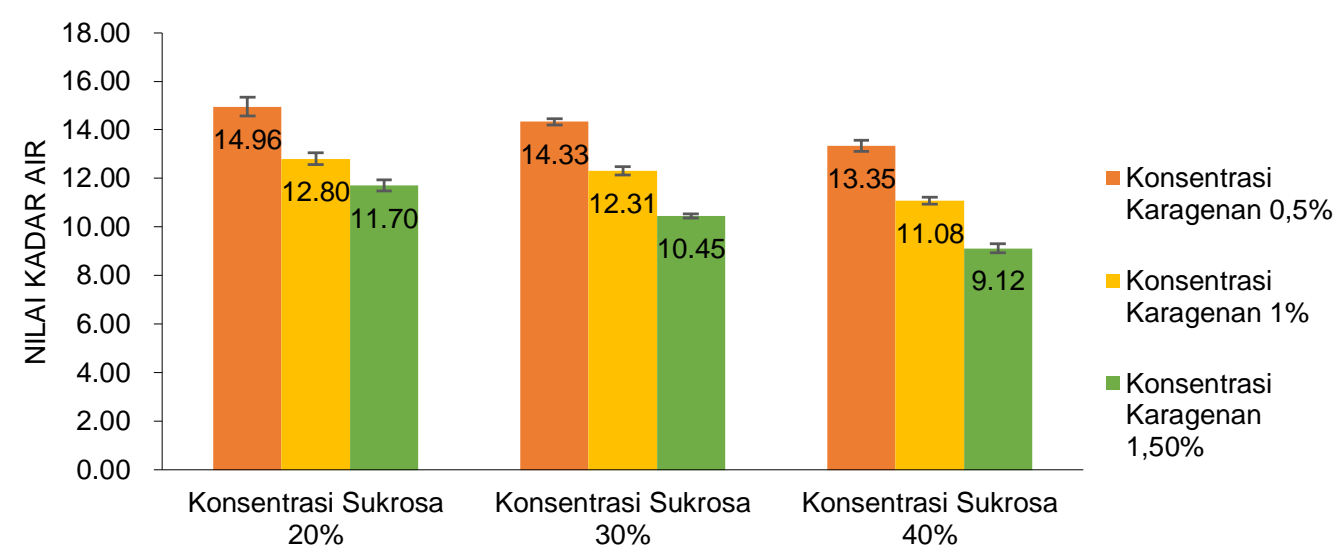

Gambar 1. Grafik Pengaruh Konsentrasi Karagenan dan Sukrosa terhadap Kadar air Fruit Leather Pisang Kepok Merah

Karagenan yang ditambahkan dalam fruit leather pisang kepok merah dapat membentuk gel, mekanisme pembentukan gel yaitu penggabungan atau pengikatan silangrantai rantai polimer sehingga terbentuk suatu jala 3 dimensi, jala tersebutlah yang menangkap atau memobilisasikan air di dalamnya membentuk struktur yg kuat dan dan kaku (Fardiaz, 1989). Karagenan bersifat mudah mengikat air sebab adanya gugus sulfat bermuatan negatif disepanjang rantai polimernya (Santoso, 2007). Gugus ester sulfat dan unit galaktopiranosa yang terdapat pada karagenan bersifat hidrofilik (Glicksman, 1983).

Semakin tinggi konsentrasi sukrosa yang ditambahkan dapat mengakibatkan kenaikan suhu pada proses pemanasan sehingga air yang teruapkan akan semakin banyak dan kadar air menurun. Hal tersebut didasarkan pada pernyataan (Medved,1986) dalam Hakim (2000) yang mengemukaakan bahwa ketika air dan gula dicampur dalam kondisi panas semua gula masuk kedalam pelarut sehingga larutan itu menjadi jenuh (tersaturasi) dan temperatur meningkat diatas temperatur titik didih air, pemanasan yang terus menerus menguapkan banyak air sehingga menjadi lebih pekat. Pernyataan tersebut didukung pula oleh Desrosier (1988) dalam Hasniarti (2012) bahwa gula dapat mengurangi air bahan dalam pemanasan produk, karena gula dapat mengurangi air yang ditahan dalam strukktur bahan.

\section{b. Total Asam}

Total asam fruit leather pisang kepok merah semakin rendah seiring penambahan konsentrasi sukrosa yang semakin tinggi, namun pada penambahan konsentrasi karagenan yang semakin tinggi total asam fruit leather pisang kepok merah cenderung stabil. Hasil analisis sidik ragam menunjukan bahwa penambahan karagenan dan sukrosa berpengaruh nyata $(\alpha=0,05)$ terhadap total asam fruit leather pisang kepok merah. Interaksi kedua perlakuan tidak memberikan pengaruh nyata $(\alpha=0,05)$ terhadap total asam fruit leather buah pisang kepok merah. Pengaruh Konsentrasi Karagenan dan Sukrosa terhadap Total Asam Fruit Leather Pisang Kepok Merah dapat dilihat pada Gambar 2. 


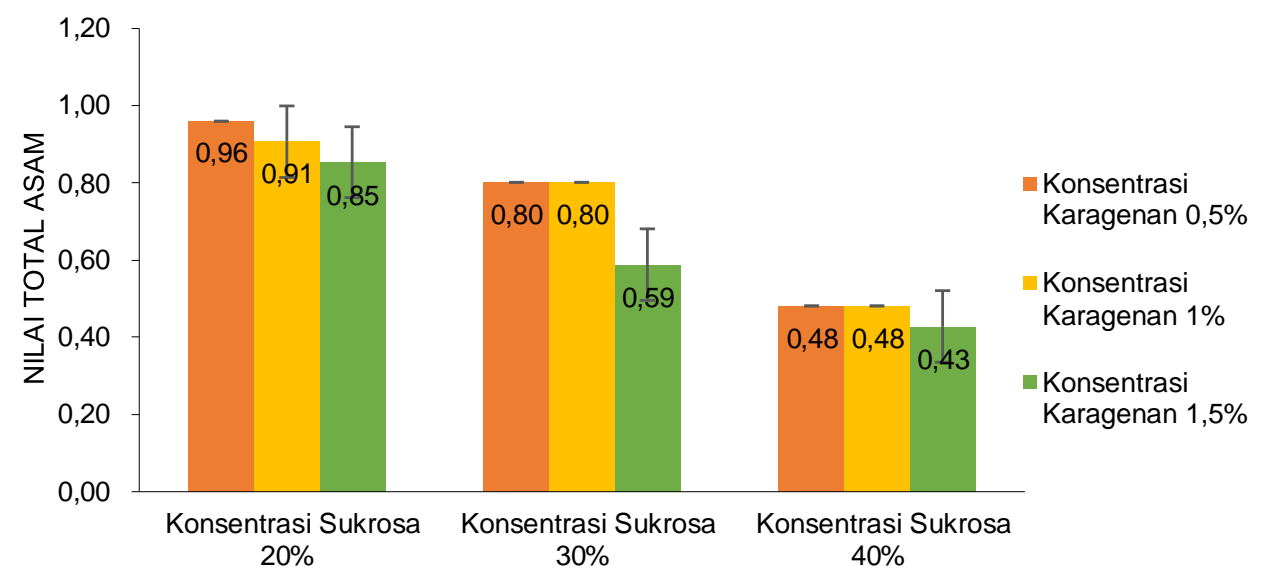

Gambar 2. Grafik Pengaruh Konsentrasi Karagenan dan Sukrosa terhadap Total Asam Fruit Leather Pisang Kepok Merah

Menurut Bangun (2009), peningkatan konsentrasi puree buah mangga tanpa dibarengi dengan penambahan gula, menyebabkan kandungan asam sitrat sebagai asam dominan juga ikut meningkat sehingga total asam pada selai lembaran terong belanda juga meningkat. Namun berbeda, jika puree buah nanas ditambahkan dengan pemanis sorbitol, maka total asam semakin rendah. Asam yang tinggi dan adanya proses pemanasan serta penyerapan air menyebabkan terjadinya reaksi hidrolisis oleh asam terhadap sukrosa membentuk fruktosa dan glukosa. Reaksi tersebut menyebabkan terjadinya penurunan kandungan total asam pada bahan karena sebagian asam digunakan untuk menghidrolisa sukrosa. Selain itu sukrosa memiliki kemampuan untuk mengkikat ion-ion $\mathrm{H}^{+}$pada asam sehingga semakin banyak ion $\mathrm{H}^{+}$yang terikat semakin banyak maka total asam akan semakin rendah (Syafitri et al., 2010).

\section{c. Total Gula}

Hasil analisis ragam menunjukkan bahwa lama penyimpanan labu kuning tidak berpengaruh nyata $(\alpha=0.05)$ terhadap kadar abu labu kuning, sedangkan metode pemasakan berpengaruh nyata $(\alpha=0.05)$ terhadap kadar abu labu kuning serta tidak terjadi interaksi antara kedua faktor. Pengaruh lama penyimpanan dan metode pemasakan terhadap perubahan kadar abrolæabu kuning dapat dilihat pada Gambar 3.

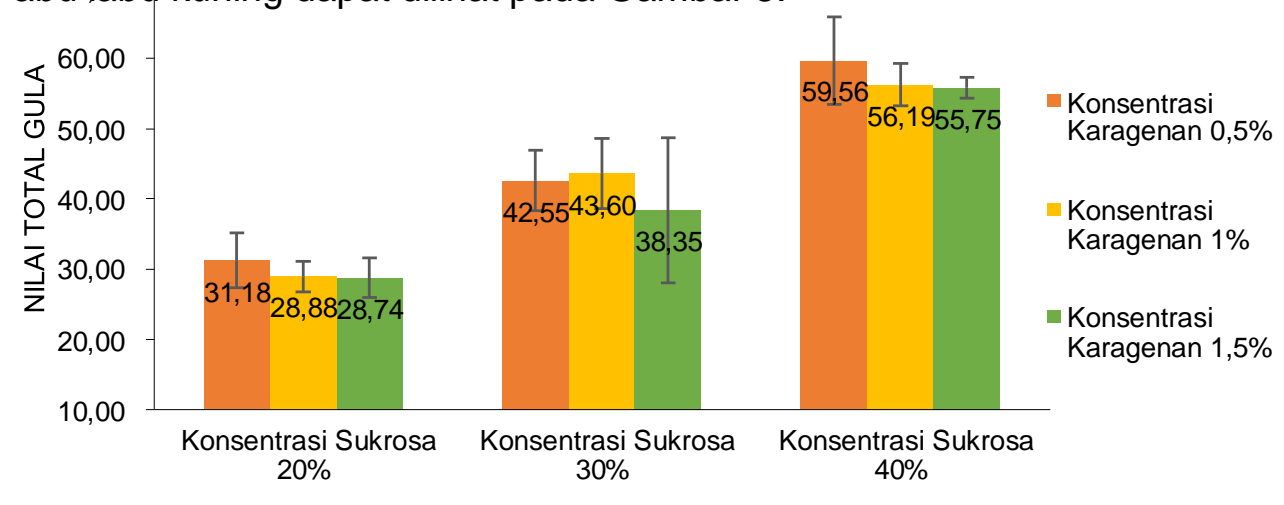

Gambar 3. Grafik Pengaruh Konsentrasi Karagenan dan Sukrosa terhadap Total Gula Fruit Leather Pisang Kepok Merah

Peningkatan konsentrasi sukrosa menyebabkan kenaikan pada total gula fruit leather pisang kepok merah. Hal tersebut disebabkan karena sukrosa merupakan salah satu jenis gula (disakarida) (Subroto, 2008). Monosakarida berupa glukosa, fruktosa, galaktosa, dan disakarida berupa laktosa dan maltosa termasuk sebagai gula pereduksi, sedangkan sukrosa merupakan gula non reduksi dan semuanya akan terhitung sebagai total gula 
(Lagho, 2010) sehingga semakin tinggi konsentrasi gula yang masuk kedalam bahan maka jumlah gula yang terukur akan semakin besar karena sukrosa terhitung sebagai total gula. Hal ini didukung oleh Hardiwijaya (2013) yang mengatakan bahwa peningkatan jumlah sukrosa yang diberikan mengakibatkan presentase total gula dalam campuran meningkat.

\section{d. $\mathrm{pH}$}

Hasil analisis ragam pada masing masing perlakuan dan interaksi antar kedua perlakuan menunjukkan adanya pengaruh nyata $(\alpha=0.05)$ terhadap $\mathrm{pH}$ fruit leather pisang kepok merah. Pengaruh konsentrasi karagenan dan sukrosa terhadap ph fruit leather pisang kepok merah dapat dilihat pada Gambar 4.

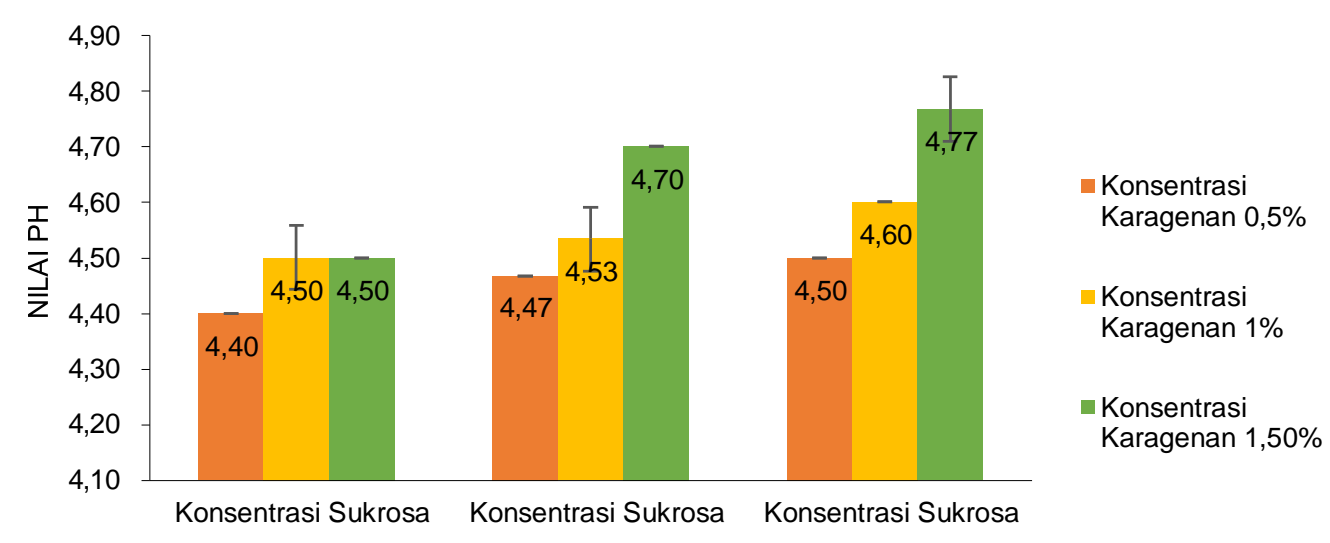

Gambar 4. Grafik Pengaruh Konsentrasi Karagenan dan Sukrosa terhadap pH Fruit Leather Pisang Kepok Merah

Nilai $\mathrm{pH}$ berbanding terbalik dengan nilai total asam, semakin rendah nilai total asam maka nilai $\mathrm{pH}$ akan semakin tinggi, semakin tinggi nilai $\mathrm{pH}$ suatu bahan menandakan bahwa bahan tersebut semakin tidak asam. Hal ini didukung oleh Sunarlim dan Misgiarta (2008) yang menyebutkan bahwa hubungan total asam tertitrasi dan nilai $\mathrm{pH}$ adalah berbanding terbalik bila total asam tertitrasi tinggi kebalikannya nilai $\mathrm{pH}$ menjadi rendah. Interaksi antar kedua faktor diduga berkaitan dengan sifat keasaman karagenan dan sukrosa yang keduanya termasuk dalam jenis karbohidrat yaitu polisakrida dan disakarida yang memiliki gugus hidroksil yang cukup banyak $(\mathrm{OH})$ sehingga dapat memberi suasana basa. Sesuai dengan pernyataan Winarno (1992) bahwa unsur yang dapat memberi suasana asam adalah ion $\mathrm{H}^{+}$ didukung oleh Lehniger (1982) yang menyatakan bahwa semakin banyak jumlah asam yang ditambahkan pada suatu larutan maka akan semakin menurun nilai $\mathrm{pH}$ nya dikarenakan ion $\mathrm{H}^{+}$yang dilepaskan semakin besar. Sehingga kombinassi kedua perlakuan penambahn konsentrasi karagenan dan sukrosa dapat menurunkan nilai $\mathrm{pH}$ dari fruit leather pisang kepok merah.

\section{e. Kadar Serat Kasar}

Hasil analisis sidik ragam menunjukkan perlakuan karagenan dan sukrosa serta interaksi antar kedua perlakuan tidak berbeda nyata $(\alpha=0.05)$ terhadap kadar serat kasar fruit leather pisang kepok merah. Pengaruh konsentrasi karagenan dan sukrosa terhadap kadar serat kasar fruit leather pisang kepok merah dapat dilihat pada Gambar 5. 


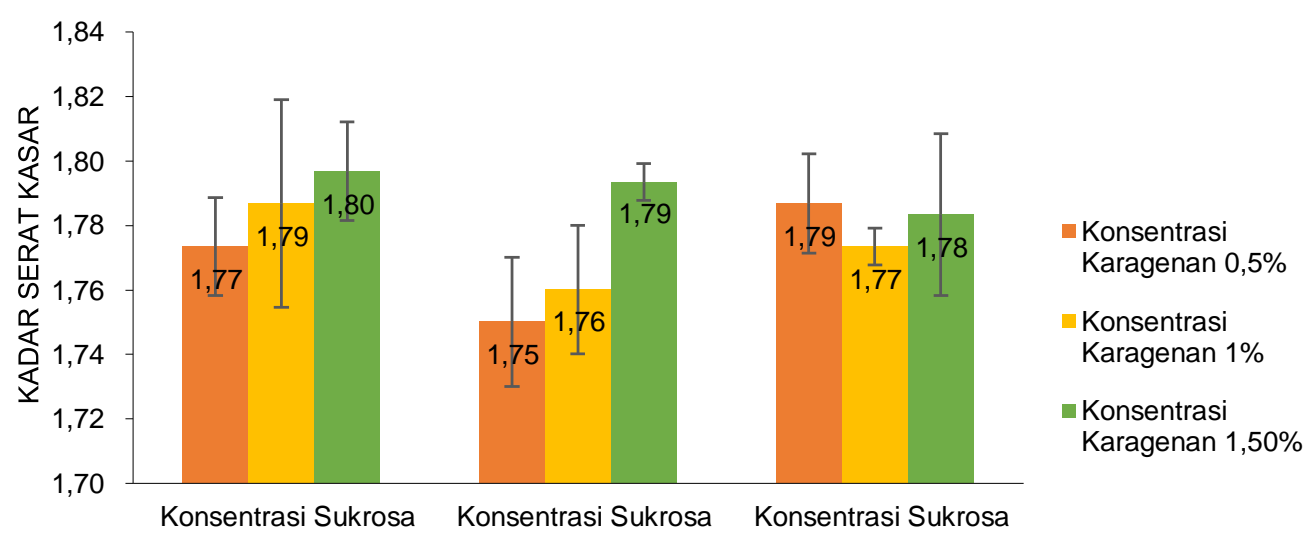

Gambar 5. Grafik Pengaruh Konsentrasi Karagenan dan Sukrosa terhadap Kadar Serat Kasar Fruit Leather Pisang Kepok Merah

Penambahan karagenan yang tidak berpengaruh pada kadar serat kasar fruit leather pisang kepok merah diduga karena karagenan termasuk dalam salah satu jenis gum (polisakarida non struktural pembentuk gel) yang merupakan bagian dari serat pangan. Hal ini didukung oleh AACC (the American Association of Cereal Chemist) (2001) serat pangan adalah merupakan bagian yang dapat dimakan dari tanaman atau karbohidrat anaalog yang resisten terhadap pencernaan dan absorpsipada usus halus dengan fermentasi lengkap atau partial pada usus besar, serat makanan tersebut meliputi pati, polisakharida, oligosakharida, lignin dan bagian tanaman lainnya. Menurut Piliang dan Djojosoebagio (2002) kadar serat kasar memiliki nilai yang lebih rendah dibandingkan dengan serat pangan karena serat pangan merupakan bagian dari bahan pangan yang tidak dapat dihidrolisis oleh enzim-enzim pencernaan sedangkan yang dimaksudkan dengan serat kasar ialah sisa bahan makanan yang telah mengalami proses pemanasan dengan asam kuat dan basa kuat selama 30 menit yang dilakukan di laboratorium, dengan proses seperti ini dapat merusak beberapa macam serat yang tidak dapat dicerna oleh manusia.

\section{Karakteristik Fisik Fruit Leather Pisang Kepok Merah}

Karakteristik fisik yang dianalisis meliputi kuat tarik, kecerahan (L), kemerahan (a), serta kekuningan (b). Rerata kuat Tarik fruit leather pisang kapok merah berkisar antara $1.03-3.27$ $\mathrm{N} / \mathrm{cm}^{2}$. Pengaruh konsentrasi karagenan dan sukrosa terhadap nilai kuat tarik fruit leather pisang kepok merah dapat dilihat pada Gambar 6.

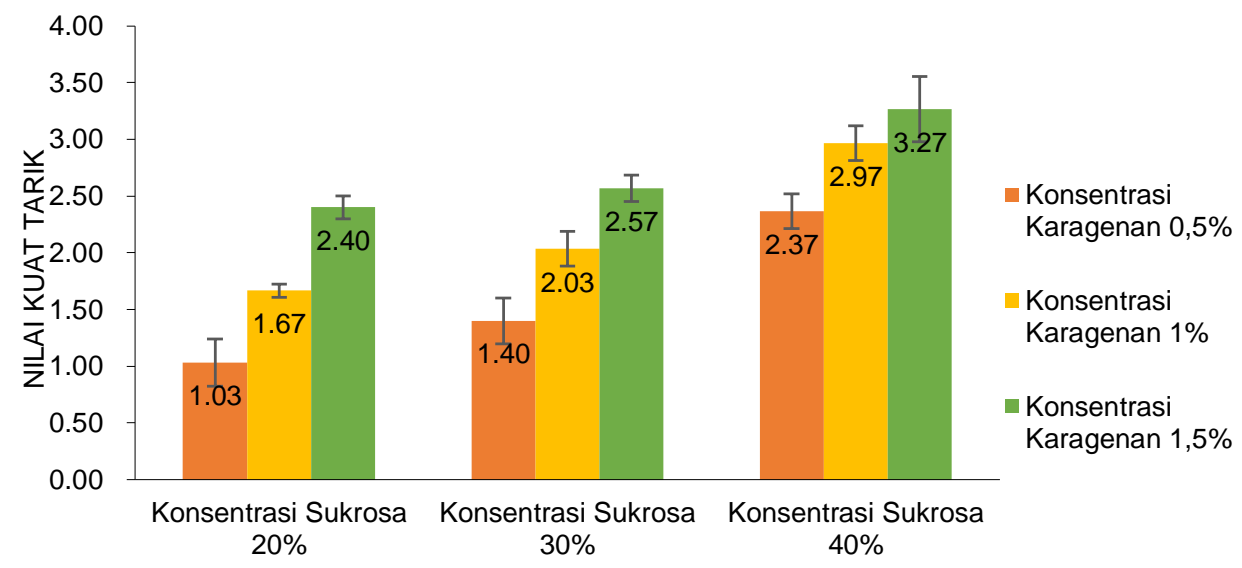

Gambar 6 Grafik Pengaruh Konsentrasi Karagenan dan Sukrosa terhadap Nilai Kuat Tarik Fruit Leather Pisang Kepok Merah

Penambahan bahan penunjang seperti gula yang larut dalam campuran akan mempengaruhi viskositas campuran, tingginya gula dan rendahnya kadar air mengakibatkan viskositas meningkat. Pernyataan ini didukung oleh Desrosier (1988) dalam Hasniarti (2012) 
bahwa gula dapat mengurangi air bahan dalam pemanasan produk, karena gula dapat mengurangi air yang ditahan dalam strukktur bahan sehingga semakin banyak sukrosa yang ditambahkan maka akan semakin berkurang air bebas dalam bahan pangan yang dapat melunakkan tekstur bahan pangan.

Selain itu karagenan memiliki sifat dapat membentuk gel dengan tekstur yang kompak dan kuat (Glicksman, 1983). Kekuatan gel karagenan dipengaruhi oleh gugus sulfat yang bermuatan negatif pada karagenan yang akan membentuk ikatan dengan ion positif dari kalium yang terkandung dalam buah pisang. Hal ini diperkuat oleh Stanciof dan Stanley (1969) dalam Mukti (1987) yang menyatakan bahwa Kation K+ dapat berfungsi sebagai bahan pengikat antar rantai polimer karagenan dengan memperkuat struktur 3 dimensi sehingga polimer tersebut akan mempertahankan bentuknya jika dikenai tekanan. Kalium yang terkandung dalam buah pisang menurut Nutritive Value of Food USDA (2002) sebesar 467 mg per $118 \mathrm{gr}$ pisang. Peningkatan nilai kuat tarik seiring dengan semakin tingginya konsentrasi karagenan dan sukrosa yang ditambahkan berhubungan dengan perubahan kadar air fruit leather pisang kepok merah.

Rerata warna fruit leather pisang kepok merah yaitu 49.93-66.83. untuk kecerahan (L), 2.00-5.10 untuk kemerahan $\left(\mathrm{a}^{*}\right)$ dan 22.50-2.90 untuk kekuningan $\left(\mathrm{b}^{*}\right)$. Hal tersebut menggindikasikan bahwa fruit leather pisang kapok merah memiliki warna yang cenderung terang dengan sedikit kemerahan dan agak kekuningan.

Untuk parameter organoleptic panelis lebih menyukai fruit leather dengan karakteristik warna yang terang dengan aroma pisang yang lebih kuat, rasa yang tidak terlalu manis dan tekstur yang lembek (tidak liat).

\section{Perlakuan Terbaik}

Pemilihan perlakuan terbaik diperoleh melalui perhitungan menggunakan metode multiple atribute Zeleny (1982) dengan pembobotan sesuai nilai ideal masing masing parameter. Penentuan perlakuan terbaik ditentukan dari parameter kimia dan fisik fruit leather pisang kepok merah meliputi kadar air, pH, total asam, kadar serat kasar, total gula, tekstur dan warna. Hasil pengujian perlakuan terbaik dapat dilihat pada Tabel 7.

\begin{tabular}{|c|c|}
\hline Parameter & Perlakuan Terbaik Metode Zeleny \\
\hline Kadar Air (\%) & 11.08 \\
\hline Total Asam (\%) & 0.85 \\
\hline Total Gula (\%) & 28.74 \\
\hline Serat Kasar (\%) & 1.80 \\
\hline $\mathrm{Ph}$ & 4.50 \\
\hline Kuat Tarik (N/cm²) & 2.40 \\
\hline \multicolumn{2}{|l|}{ Warna } \\
\hline Nilai L & 63.43 \\
\hline Nilai $\left(a^{\star}\right)$ & 3.73 \\
\hline Nilai $\left(b^{\star}\right)$ & 23.10 \\
\hline \multicolumn{2}{|l|}{ Organoleptik } \\
\hline Warna & 2.68 \\
\hline Aroma & 2.88 \\
\hline Rasa & 2.95 \\
\hline Tekstur & 2.87 \\
\hline Keseluruhan & 2.92 \\
\hline
\end{tabular}




\section{SIMPULAN}

Hasil analisis ragam (ANOVA) menunjukkan perbedaan penambahan karagenan memberikan pengaruh nyata $(\alpha=0,05)$ terhadap kadar air, total asam, $\mathrm{pH}$, tekstur, nilai kecerahan $\left(\mathrm{L}^{*}\right)$ dan nilai kemerahan $\left(\mathrm{a}^{*}\right)$, parameter warna, rasa, tekstur dan keseluruhan karskteristik organoleptik fruit leather pisang kepok. Hasil analisis ragam (ANOVA) menunjukkan perbedaan penambahan sukrosa memberikan pengaruh nyata terhadap kadar air, total asam, $\mathrm{pH}$, total gula, tekstur, kecerahan $\left(\mathrm{L}^{*}\right)$ dan nilai kemerahan $\left(\mathrm{a}^{\star}\right)$ parameter warna, rasa, tekstur dan keseluruhan karskteristik organoleptik fruit leather pisang kapok. Perlakuan terbaik dihasilkan dari kombinasi perlakuan karagenan $1.50 \%$ dan sukrosa $20 \%$ dengan kadar air sebesar $11.08 \%$, total asam $0.85 \%$, total gula $28.74 \%$, serat kasar $1.80 \%$, $\mathrm{pH} 4.50 \%$, nilai kecerahan $\left(\mathrm{L}^{*}\right) 63.40$; nilai kemerahan $\left(\mathrm{a}^{*}\right) 3.73$; nilai kekuningan $\left(b^{*}\right)$ 22.90; nilai kesukaan parameter warna 2.68; nilai kesukaan parameter rasa 2.88; nilai kesukaan parameter aroma 3.03; nilai kesukaan parameter tekstur 2.95 dan nilai kesukaan keseluruhan karakteristik 2.93.

\section{DAFTAR PUSTAKA}

AACC. 2001. The Definition of Dietary Fiber. Cereal Fds. World.

Bangun. 2009. Pengaruh Konsentrasi Gula Dan Campuran Sari Buah Terhadap Mutu Serbuk Epetani,Pertanian. 2010. Pembuatan Fruit Leather Dari Campuran Buah Nanas dan Pisang. http://m.epetani. Deptan. go. Id. Diakses pada 5 januari 2018.

Fardiaz,.1989. Hidrokoloid. Laboratorium Kimia dan Biokimia Pangan, Pusat Antar Universitas Pangan dan Gizi, Institut Pertanian Bogor, Bogor.

Glicksman, M. 1969. Gum Technology in The Food Industry. Academic Press. New York.

Hakim, Meike Sketsa, 2000. Karakteristik Karamel Susu dengan Penambahan Kacang Kedelai (Glicine Max (L) Merrill ). Skripsi Fakultas Peternakan IPB. Bogor.

Hardiwijaya. 2013. Pengaruh Perbedaan Penambahan Gula Terhadap Karakteristik Sirup Buah Naga Merah. Jurnal Fakultas Pertanian, Universitas Andalas, Padang.

Hasniarti. 2012. Pembuatan Permen Buah Dengen (Dillemia serrate Tumb). Skripsi. Fakultas Pertanian. Universitas Hassanudin Makkasar.

Ishma N S. 2017. Total Bakteri Asam Laktat, Total Asam, Nilai pH, Viskositas, Aktivitas Antioksidan dan Sifat Organoleptik Yogurt dengan Penambahan Jus Buah Tomat. Skripsi. Universitas Diponegoro Semarang.

Lagho A.B.A. 2010. Pembuatan Basis Data Struktur Tiga Dimensi Senyawa Kimia dari Tanaman Obat Di Indonesia. Fakultas Matematika dan Ilmu Pengetahuan Alam. Universitas Indonesia. Depok.

Mukti F.D.W., 1987. Ekstraksi dan Analisis Sifat Kimia Karagenan dari Rumput Laut Jenis Eucheuma cottoni. Skripsi. Fakultas Teknologi Pertanian Bogor.

Musfiroh I, W Indriyati, Muchtaridi dan Y Setiya. 2009. Analisis Proksimat dan Penetapan Kadar $\beta$-Karoten dalam Selai Lembaran Terung Belanda dengan Metode Spektrometri Sinar Tampak. Jurnal Penelitian Fakultas Farmasi Universitas Padjadjaran. Bandung

Nurlaely E. 2002. Pemanfaatan Jambu Mente untuk Pembuatan Fruit Leathrer Kajian Proporsi Buah Pencampur. Skripsi. Universitas Brawijaya Malang.

Offia-Oula B.I, and O.A Ekwunive . 2015. Production And Evaluation of The Physico-Chemical And Sensory Qualities of Mixed Fruit Leather and Cakes Produced from Apple (Musa Pumila), Banana (Musa Sapientum), Pineapple (Ananas Comosus). J. Nigerian Food (33):22-28

Piliang W.G, dan S Djojosoebagio Al Haj. 2002. Fisiologi Nutrisi. Vol. I. Edisi Ke-4. IPB Press, Bogor.

Santoso J. Yumiko Y., and Takeshi S. 2004. Mineral, Fatty Acid, and Dietary Fibre Compositions in Several Indonesian Seaweeds. Jurnal IImu Perairan dan Perikanan Indonesia. Vol II No 1: 44-45. 
Santoso J, Gunji S, Yoshie-Strak Y, and Suzuki, T. 2006. Mineral Content Of Indonesian Seaweed and Mineral Solubility Affected by Basic Cooking. Food Science and Tecnology Research. 12(1): 59-66.

Subagio. 2007. Kadar Gula Dalam Makanan. Jakarta. Gramedia.

Subroto,A. 2008. Pemanfaatan Tepung Bekatul Rendah Lemakpada Pembuatan Keripik Stimulasi. Jurnal Gizi dan Pangan, 2016 1:2 34-44.

Sunarlim, $R$ dan Misgiarta. 2008. Kombinasi $L$ plantarum dan $L$ burgaricus dan $S$ Thermophilus Terhadap Mutu Susu Fermentsi Selama Proses Penyimpanan. Hal 312316.Prosding Seminar Nasional teknologi Peternakan dan Puslitbangnak. Bogor.

Surendranathan, K.K., Ramaswamy, N.K., Radhakrishna, P., and Nair, J.S., 2003. Value Added Product from Ripe Banana Powder. BARC Newsletter, March 28-29 2003 :188190.

Syafitri et al. 2010. Formula Media Pertumbuhan Bakteri Asam Laktat Pediococus pentosaceus Menggunakan Substrat Whey Tahu. Jurnal Sumberdaya Hayati Vol 2 No. 2 halaman 31-38.

USDA. 2016. Nutrient Values And Weight For Banana Raw For Edible Portion. United States Department of Agriculture, WashingtonDC. www.ndb.nal.usda.gov.

Winarno F.G., 1990. Teknologi Pengolahan Rumput Laut. CV. Muliasa, Jakarta.

Winarno F.G, dan Fardias.1980. Pengantar Teknologi Pangan. PT. Gramedia, Jakarta.

Yuliawati R., 2014. Outlook Komoditas Pertanian Sub Sektor Holtikultura. Pusat Data dan Sistem Informasi Pertanian. Kementrerian Pertanian. 